Transitioning in Higher Education: An exploration of psychological and contextual factors affecting student satisfaction

Charlotte R. Pennington ${ }^{1}$, Elizabeth A. Bates ${ }^{2}$, Linda K. Kaye ${ }^{* 1}$, \& Lauren T. Bolam ${ }^{2}$

${ }^{1}$ Edge Hill University, UK; ${ }^{2}$ University of Cumbria, UK

*Corresponding Author at:

${ }^{1}$ Department of Psychology, Edge Hill University, St Helen's Road, Ormskirk, Lancashire, UK, L39 4QP

Email: Penninc@edgehill.ac.uk

Tel: +44 1695657587

${ }^{2}$ Department of Psychology, University of Cumbria, Fusehill Street, Carlisle, Cumbria, CA1 $2 \mathrm{HH}$

Email: Elizabeth.Bates@cumbria.ac.uk Tel: +44 1228616358

${ }^{1}$ Department of Psychology, Edge Hill University, St Helen's Road, Ormskirk, Lancashire, UK, L39 4QP

Email: Linda.kaye@edgehill.ac.uk Tel: +44 1695584413

${ }^{2}$ Department of Psychology, University of Cumbria, Fusehill Street, Carlisle, Cumbria, CA1 $2 \mathrm{HH}$

Email: $\underline{\text { S1106364@uni.cumbria.ac.uk }}$ 


\section{Transitioning in Higher Education: An exploration of psychological and contextual factors affecting student satisfaction}

In view of recent changes in the Higher Education sector, such as increased tuition fees, a greater focus has been placed on widening participation initiatives and monitoring student satisfaction. The aims of the current study were twofold: 1), to explore whether pre-entry programmes foster successful transition to higher education, and 2), to examine longitudinally the factors associated with course satisfaction. Eighty-eight first year Psychology students completed a questionnaire measuring academic self-efficacy, social identity and student satisfaction at the start (Time 1, November 2015) and end of the academic year (Time 2, March 2016). Findings indicated that students who participated in a pre-entry programme reported higher academic self-efficacy and satisfaction compared to typical route students. Moreover, academic self-efficacy predicted student satisfaction at the start of the academic year, whereas in-group affect (a facet of social identity) predicted this at the end of the academic year. The current findings indicate that pre-entry programmes may have a positive impact on students' sense of academic self-efficacy. On a more general level, the findings also suggest that academic self-efficacy and social identity may be key indicators of student satisfaction. This highlights the complexities of the concept of "student satisfaction", and demonstrates the utility of examining multiple factors relating to student satisfaction across different time points.

Key words: transition; pre-entry programmes; academic self-efficacy; social identity; satisfaction 


\section{Transitioning in Higher Education: An exploration of psychological and contextual factors affecting student satisfaction}

For many students, entering higher education requires considerable adjustment (Yorke, 2000) and may be perceived as a significant challenge (Murtagh, 2012). Compared to the 'controlled' environment of further education institutions, students in higher education are responsible for their own achievement ${ }^{1}$ (Yorke, 2000; Yorke \& Longden, 2008). This experience can be overwhelming and contribute to heightened levels of anxiety and stress (Lowe \& Cook, 2003). During the transition period, students therefore need to form a sense of their student identity (Huon \& Sankey, 2002; Leese, 2010; Scanlon, Rowling, \& Weber, 2005) and learn to act autonomously as independent learners (Fazey \& Fazey, 2001).

Establishing a positive learner identity has thus been identified as an essential factor in the persistence and success of a university student (Briggs \& Hall, 2012).

In order to attract and retain students, universities must identify and meet student expectations (Elliot \& Healy, 2001). However, students' pre-transfer aspirations and expectations have been shown to diverge from the reality of their first year at university, which may translate into difficulty adapting to higher education (Bates \& Kaye, 2014; Tranter, 2003; Reay, Crozier, \& Clayton, 2010; Smith \& Hopkins, 2005). Research suggests that students receive inadequate information prior to entering university, resulting in them making inappropriate decisions regarding their choice of institution and course (Harvey \& Drew, 2006; Krause, Hartley, James, \& McInnis, 2005; McInnis, James, \& Hartley, 2000; Yorke, 2000). Many students also report feeling underprepared for university, with this being a key indicator of withdrawal (Forrester, Motteram, Parkinson, \& Slaouti, 2004; Richardson,

\footnotetext{
${ }^{1}$ Further education (FE) in UK education is a stage of study after secondary education (post16 years), which precedes Higher Education (university/degree level study).
} 
2003; Thomas, 2012; Quinn et al., 2005). For example, Thomas (2012) found that "courserelated issues" were the most commonly stated reason for students thinking about leaving higher education, with $74 \%$ reporting that they felt underprepared for university. Raey et al. (2010) also found that students felt that they were expected to be independent learners upon entering university, but received insufficient advice and supervision in this regard. Systems of planned transition between schools and universities, as well as mechanisms to ensure informed decisions on course and university choices, are therefore important and may increase retention, student satisfaction and achievement (Berger \& Malaney, 2001; Dodgson \& Bolam, 2002, Smith, 2002; Yorke \& Thomas, 2003). From this perspective, pre-entry programmes may contribute to student satisfaction because they provide information, knowledge and skills to improve decision-making, assist in the development of realistic expectations and preparation, and foster early engagement to promote integration and social capital (Thomas, 2012).

On a more general level, student satisfaction is cited as a key factor in the context of successful transition and retention, particularly when considering that low satisfaction is associated with university attrition rates (Nevill \& Rhodes, 2004; Thomas, 2012). With this in mind, research has explored the role of student factors in experiences of academic satisfaction, including learning approach, self-efficacy and a sense of belonging (Bates \& Kaye, 2014; Sanders \& Higham, 2012). Less research, however, has examined the role of pre-entry programmes in fostering these key psychological factors. Bridging this gap in the literature, the current research proffers a model to suggest that pre-entry programmes may foster positive transitional experiences by increasing academic self-efficacy and facilitating students' integration within university, and that these factors may be predictive of student satisfaction throughout the academic year. 


\section{Academic self-efficacy}

Self-efficacy beliefs have been found to be associated with perseverance, resilience and achievement in educational settings, particularly the ability to cope with the demands of a chosen course of study (Bandura, 1986, 1997; Chemer et al., 2001; Schunk, 1995). Research suggests that academic self-efficacy is strongly related to a number of academic outcomes, including adjustment (Chemer, Hu, \& Garcia, 2001; Ramos-Sanchez \& Nichols, 2007), satisfaction (Lent, Singley, Sheu, Schmidt, \& Schmidt, 2007), motivation (Schunk \& Ertmer, 1999), and retention (DeWitz, Woolsey, \& Walsh, 2009). Exploring ways of enhancing students' academic self-efficacy is therefore of practical significance, and pre-entry programmes may present as one effective means of achieving this. For example, research documents the effectiveness of pre-entry interventions for preparing nursing students for their training, particularly in fostering confidence and self-efficacy (Fergy, Heatley, Morgan, \& Hodgson, 2008), and academic achievement (Brimble, 2013). It should be noted, however, that researchers have not found this to be the case in other domains (Brooman \& Darwent, 2014). The current research therefore examined the effectiveness of pre-entry programmes in increasing Psychology students' academic self-efficacy, and investigated further whether this is associated with student satisfaction throughout the first year of university.

\section{Social identity}

Another important factor which may influence students' transition experiences is that of feeling socially integrated and connected with others (Brooman \& Darwent, 2014; Hutchinson, Mitchell, \& St John, 2011; O’Donnell \& Tobbell, 2007; Warin \& Dempster, 2007). Research suggests that a sense of positive social environment may determine students' choices of specific higher education institutions (HEIs; Kaye \& Bates, 2016) and inform their decisions to remain in HE (Sanders \& Higham, 2012; Thomas. 2012). Previous research has 
also demonstrated how aspects of social identity (i.e., identity as a university student) can support numerous university experiences, such as transition (Crafter \& Maunder, 2012; Maunder, Gingham \& Rogers, 2010; O’Shea, 2014), well-being (Iyer, Jetten, Tsivrikoos, Postmes, \& Haslam, 2009), commitment to attend university (Howard \& Davies, 2013) and satisfaction (Wilkins, Butt, Kratochvil, \& Balakrishnan, 2015). Moreover, these identity processes have been found to predict successful transition beyond university and in to the workplace (Jungert, 2013).

Although previous research has explored a number of theoretical explanations of social belonging and identity processes for enhancing student transition and retention (e.g., Thomas, 2012), the current research focuses exclusively on psychological theory which can underpin experiences of social belonging and affiliation in educational contexts. Social identity theory (SIT; Tajfel, 1978, 1979; Tajfel \& Turner, 1979) posits that individuals are motivated to feel positively about the self, and they fulfil this motivation by identifying with valued social groups (Hogg \& Abrams, 1988). A core facet of this theory is social identification, whereby an individual's identity is formulated by their experiences within a social group. At this point, affiliations with 'in-groups' and 'out-groups' are made, and a mergence of personal sense of self and sense of self as a group member is established to promote self-esteem (i.e., the collective self; Ellemers, Gilder, \& Haslam, 2003). It is therefore apparent that students' successful transition to university may be underpinned by a positive sense of group identity and membership, and this may be facilitated by the implementation of pre-entry programmes. Whilst pre-entry programmes are primarily designed to provide an overview of the chosen course of study (e.g., introduction to the subject, taster sessions, academic skills workshops), they also incorporate a 'social' component (e.g., existing students as mentors, group work projects). Focusing on the latter, research suggests that peer mentors are instrumental in developing students' sense of 
belonging and fostering successful transition and retention (Sanders \& Higham, 2012). As such, it is conceivable that pre-entry programmes may successfully shape multiple facets of social identity, such as a sense of affiliation to a specific HEI (i.e., in-group affect), belonging in various social groups (i.e., in-group ties) and positive self-concept as a student (i.e., cognitive centrality). The current research therefore explored the extent to which pre-entry programmes foster academic self-efficacy and social identity. It also examined whether these key psychological factors are associated with successful transition experiences throughout students' first year of academic study. Accordingly, the current research was underpinned by the following research questions, which are presented visually in Figure 1:

RQ1: What is the role of pre-entry programmes in enhancing social identity, academic selfefficacy and student satisfaction?

RQ2: To what extent are social identity and academic self-efficacy related to course satisfaction within the first year of university?

\section{[Figure 1 about here]}

\section{Method}

\section{Participants}

A convenience sample of 88 first year undergraduate Psychology students from two UK HEIs completed pen-and-paper questionnaires that measured student satisfaction, academic selfefficacy and social identity at the start (Time 1, November 2014) and end of the academic year (Time 2; March 2015) ${ }^{2}$. Following a scheduled module session, questionnaires were distributed to students and they were asked to complete them in their own time, and return to the researchers within a one-week period. Of those who returned the questionnaires, 74

\footnotetext{
${ }^{2} 88$ out of a total of 131 students completed both questionnaires at Time 1 and Time 2 resulting in a follow up success rate of $67 \%$.
} 
(84.1\%) represented traditional students who entered directly into university from full-time education, compared to $14(15.9 \%)$ who were mature students. As part of a widening participation initiative at both institutions, $15(17 \%)$ students had participated in one of three pre-entry programmes rolled out at the University of Cumbria (HeadStart Scheme) and Edge Hill University (Summer Residential and Fast-track course) and were thus self-selecting. All three of these programmes are based around developing subject knowledge and skills relevant for undertaking a Psychology undergraduate course. Although the courses vary in the intensity of content coverage and opportunities for social events, all entail engagement with the specific institution and course of students' chosen university course, thus allowing students to gain a sense of belonging to the university and a sense of the student experience at that institution.

\section{Materials}

Students supplied demographical information such as their gender, university, student status (traditional or mature), and whether or not they had attended a pre-entry programme before starting their course of study. Three questionnaires then examined self-reported satisfaction, academic self-efficacy and social identity.

\section{Social identity}

Social identity was measured using the Three-Dimensional Strength of Group Identification Scale (Cameron, 2004). This measure was selected based on its utility to assess multidimensional components of social identification, which is important within a complex environment such as HE (Obst \& White, 2005). This 12-item scale consists of three subscales; cognitive centrality (e.g., 'I often think about being a Psychology student at Edge Hill University); in-group ties (e.g., 'I feel strong ties to other Psychology students at Edge Hill University"), and in-group affect (e.g., 'I am glad to be a Psychology student at Edge 
Hill University'). Students endorsed their agreement to the items on a 7-point scale anchored between 1 (Strongly Disagree) and 7 (Strongly Agree). This questionnaire resulted in high internal consistency at both time-points. Specifically, in-group ties ranged from $\alpha=0.80$ to 0.91 ; centrality from $\alpha=0.68$ to 0.76 ; and in-group affect from $\alpha=0.79$ to 0.81 . Previous research has supported the factor structure of this scale and indicates that it is a valid measure of ingroup identification (Obst \& White, 2005).

\section{Academic self-efficacy}

An adapted version of the Academic Self-efficacy Scale (ASES; Schmitt, 2008) was utilised to measure students' academic self-efficacy in relation to their perceived achievement in higher education. The ASES comprises four items such as 'I believe I can achieve good grades in University' and students responded on a 5-point scale anchored between 1 (Strongly Disagree) and 5 (Strongly Agree). This questionnaire resulted in high internal consistency at both Time 1, Cronbach's $\alpha=0.85$, and Time 2, $\alpha=0.86$. Previous research has shown that this scale is a reliable measure of academic self-efficacy and concurrent validity has been confirmed with scores correlating with students' grade point average (Schmitt, 2008).

\section{Satisfaction}

Satisfaction was measured using an adapted version of the First Year Experience in Australian Universities Scale (FYEQ; James, Krause, \& Jennings, 2010). For the purposes of the current study, the sub-scales of course satisfaction (three items), teaching (nine items) and academic orientation (six items) were selected in order to assess satisfaction from varying dimensions. Participants responded to questions such as 'Overall I am really enjoying my course', 'The teaching staff are good at explaining things' and 'I enjoy the intellectual 
challenge of the subjects I am studying' on a Likert scale anchored between 1 (Strongly Disagree) and 5 (Strongly Agree). This 18-item questionnaire resulted in high internal consistency at Time 1 and Time 2, both Cronbach's $\alpha=0.92$ and previous research has supported the construct validity of each of the employed sub-scales (James et al., 2010).

\section{Results}

A between-participants analysis was conducted to examine whether pre-entry students reported higher academic self-efficacy, social identity and student satisfaction relative to those who did not participate in a pre-entry course. Non-parametric tests were deemed appropriate given the unequal sample sizes between those who participated in the pre-entry programmes $(n=15)$ compared to typical route students $(n=73)$ (Zimmerman, 1987). A series of Mann-Whitney $U$ tests indicated that students who participated in a pre-entry programme reported higher self-efficacy at the start of the academic year (Time $1 ; M d n=$ 56.63) compared to non-pre-entry students $(M d n=42.01), U=385.50, p<0.05, r=-0.22$. Moreover, pre-entry students reported higher satisfaction at the start of the academic year (Time 1; $M d n=60.53)$ compared to non-pre-entry students $(M d n=41.21), U=307.00, p<$ $.05, r=-0.28$. Social identity did not differ as a function of pre-entry programme, $p>0.05$. Both pre-entry and non-pre-entry students reported similar levels of self-efficacy, satisfaction and social identity at the end of the academic year (Time $2, p>0.05$ ). Table 1 presents descriptive statistics of each study variable between time points and entry programme.

\section{[Table 1 about here]}

A within-participants regression analysis was then conducted to examine whether academic self-efficacy and social identity were predictive of student satisfaction at the start and end of the academic year. Findings indicated that academic self-efficacy predicted satisfaction at 
Time $1(\beta=0.36, t=3.64, p<0.001)$. However, social identity $(\beta=-0.29, t=-0.16, p=$ $0.88)$, including the sub-scales of centrality $(\beta=0.02, t=0.03, p=0.98)$, in-group affect $(\beta=$ $0.44, t=0.61, p=0.54)$ and in-group ties $(\beta=0.15, t=0.15, p=0.88)$ did not predict satisfaction. The overall regression model was found to be significant $(F(5,87)=7.02, p<$ 0.001 ), and the adjusted $\mathrm{R}^{2}$ value indicated that $26 \%$ of the variance in satisfaction was accounted for by the predictor variables at this time point. See Table 2 for regression matrix.

\section{[Table 2 about here]}

At Time 2, in-group affect significantly predicted student satisfaction $(\beta=.63, t=4.02, p<$ $.001)$. However, total social identity $(\beta=-0.17, t=-0.40, p=.69)$, and the sub-scales of centrality $(\beta=.15, t=.59, p=.56)$, and in-group ties $(\beta=-0.12, t=-0.52, p=0.61)$ were not predictive of satisfaction at this time point. Additionally, academic self-efficacy did not predict satisfaction at the end of the academic year $(\beta=0.14, t=1.49, p=0.14)$. The overall regression model was found to be significant $(F(5,87)=9.75, p<.001)$, and the adjusted $\mathrm{R}^{2}$ value indicated that $34 \%$ of the variance in satisfaction was accounted for by the predictor variables. See Table 3 for regression matrix.

[Table 3 about here]

\section{Discussion}

The current research examined the effectiveness of pre-entry programmes in enhancing students' academic self-efficacy, satisfaction and social identity. Findings revealed that students who participated in a pre-entry programme reported higher academic self-efficacy and satisfaction compared to their non-pre-entry counterparts within the first few weeks of 
their academic study. However, social identity did not differ between pre-entry and typical route students. The current study also examined longitudinally whether academic selfefficacy and social identity predicted student satisfaction throughout students' first year of university. Findings indicated that academic self-efficacy predicted satisfaction at the start of the academic year, whereas in-group affect (a facet of social identity) predicted this at the end. These findings therefore suggest that pre-entry programmes may foster positive educational experiences and demonstrate further that student satisfaction may be influenced by different factors across different time points.

The finding that academic self-efficacy was significantly higher for students who had engaged in a pre-entry programme may highlight the utility of such transitional events in enhancing students' confidence through both the coverage of subject content and the teaching of relevant skills required for university study (e.g., using online resources, referencing). This supports previous research demonstrating the effectiveness of pre-entry interventions in increasing student nurses' academic self-efficacy (Fergy et al., 2008), whilst also highlighting the value of such programmes in other fields of study (i.e., Psychology). Furthermore, the benefits of such programmes may translate into other important academic outcomes such as attainment, particularly when considering the extent literature demonstrating the inherent links between self-efficacy and performance outcomes (Brimble, 2013; Chemers, Hu \& Garcia, 2001; Pajares, 1996). Nevertheless, within both the current and previous research, it is important to question whether the observed differences in academic self-efficacy between pre-entry and typical route students is entirely attributable to attendance on these programmes or due to pre-existing differences between students. From this perspective, it is conceivable that students who opted to take part in this programme were mindful about their success and achievement in education, and thus, may have had a more general positive approach to their own learning compared to those who did not participate. In line with this suggestion, 
Broonam and Darwent (2014) compared students' self-efficacy before and after they had undertook a pre-entry programme, and found that academic self-efficacy did not increase during this time. Future research would therefore benefit from utilising baseline measures in order to ascertain fully the impact that pre-entry programmes have on academic self-efficacy.

Findings also revealed that students who participated in pre-entry programmes reported greater satisfaction relative to their non-pre-entry counterparts at the start of the academic year (Time 1). Pre-entry programmes may thus heighten satisfaction because they provide students with information about their course and university, which assists in the development of realistic expectations upon entering university. Consistent with this notion, research has shown that students report feeling underprepared for university (Thomas, 2012), and receive little guidance and supervision early on in their course with regard to the skills required to become independent learners (Raey et al., 2010). It is therefore plausible that the utility of pre-entry programmes lies within their ability to prepare students for higher education by shaping expectations, facilitating appropriate institutional and course choices, and building engagement and belonging (Bates \& Kaye, 2014; Thomas, 2012). Investing time and resources into structuring students' beliefs within early transition stages to higher education may therefore be considered a key recommendation for institutional policy (Bates \& Kaye, 2014). This would align with current institutional agendas which aim to promote student diversity and equity. With this in mind, pre-entry programmes may provide an opportunity for both traditional and non-traditional students to prepare for learning in a higher education setting. However, there are still concerns about inequality of access to university for socio-economically disadvantaged students (Department for Education Skills, 2003; 2006). This research thus provides empirical evidence to support the initiation of preentry interventions and the influential benefits they may have on students entering higher education. 
Against predictions, however, findings indicated that social identity did not differ between students who participated in a pre-entry programme relative to those who did not. This is in contrast to previous research demonstrating how aspects of identity can support transition (e.g., Crafter \& Maunder, 2012), general perceptions of "fitting in" (Warin \& Dempster, 2007) and the development of personal learner identities (Reay et al., 2010). One explanation for these conflicting findings may be that social identity is a construct that develops and strengthens throughout the academic year. For example, students may develop closer bonds with other students as they progress through university and become more familiar with their institution and course. As such, identifying as a university student may be a process that occurs beyond induction, when the student has adjusted to their new learning environment and becomes an integrated member of various social groups. Indeed, this may particularly be the case when considering the current finding indicating that in-group affect (a facet of social identity) predicted student satisfaction at the end of the academic year (Time 2) but not at the start (Time 1).

An additional explanation for these findings may relate to the wording of the items of the current instruments, in framing social identity towards a conception of the self as a Psychology student at the particular HEI. Specifically, it is conceivable that a sense of affiliation to either a), being a Psychology student and b), being a student at a particular HEI may operate differently. For example, some interventions may foster a sense of social identity in terms of belonging to an institution or to a particular course. Others may focus on specific parts of a students' social identity, such as encouraging friendship groups (in-group ties), the salience of a group membership to a person's self-concept (centrality), or the emotional evaluation of such group memberships (in-group affect). It is therefore conceivable that the pre-entry programmes did indeed foster social identity, but that our research instruments were unable to capture this reliably. Taking this into consideration, future investigation that 
elucidates the mechanisms underpinning social identity in pre-entry programmes would be beneficial. Specifically, it would be practically useful to gain further understanding of the specific strategies used within pre-entry programmes and their role in enhancing selfefficacy, social identity and satisfaction, as well as how these interventions may be best implemented within different subject areas. Insights into the balance of focus on academic skill development compared to social integration activities in such events could therefore be beneficial in understanding their respective contribution to students' psychological perceptions and experiences associated with their first year of university.

Finally, it is important to note that the uptake of the pre-entry programmes across the two universities was relatively low and this may have resulted in issues with the statistical power of the data. Future research that utilises larger sample sizes or pools data from a number of universities is therefore recommended to examine whether pre-entry programmes enhance social identity and contribute to successful transition experiences. In a similar vein, issues regarding small sample sizes may highlight the need for higher education policies and institutions to engage in efforts to promote the benefits of pre-entry programmes and to encourage an increase in student uptake. In the long-term, this may have a positive impact on retention rates and student satisfaction.

A second aim of the current research was to examine longitudinally whether academic self-efficacy and social identity were predictive of students' satisfaction within their first year of higher education. Findings indicated that academic self-efficacy predicted course satisfaction at the start of the academic year (Time 1), whereas in-group affect predicted course satisfaction at the end of the academic year (Time 2). The finding that academic selfefficacy was related to student satisfaction when students entered their first year of higher education is encouraging and may suggest that confidence is an important factor in successful university transition (e.g., Chemer et al., 2001). Here, academic self-efficacy may foster 
academic resilience, which in turn helps students to adjust in a different learning environment to which they are used to experiencing (Yorke, 2000).

It is promising to see some initial evidence emerging with regard to how students' membership in social groups and their affiliation with the university may strengthen as they progress through their academic studies, and the positive impact this may have on satisfaction. This finding supports previous research, which highlights that peer relationships and sense of belonging may be beneficial in informing students' decisions to stay in HE (Saunders \& Higham, 2012) and contribute to satisfaction (Wilkins et al., 2015). Pragmatically, social identity to one's subject and/or institution can be achieved through initiatives that promote social integration between learners such as group-based assessments, and also peer mentoring schemes to foster positive supportive environments (McLoughlin, Brady, Lee \& Russell, 2007). This pertains to the notion that "transition" should be viewed as a more fluid and enduring component of the university experience, which extends beyond "Induction week" across the duration of the first year. Therefore, practical and long-term efforts to maintain relational strategies between peer-networks should be a key theme within the workings of HE delivery.

On a practical level, demonstrating that different variables predict student satisfaction between the two time-points is also noteworthy. Indicators of satisfaction such as the National Student Survey (NSS) are obtained typically within the final year of study, towards the end of the academic year. Although the focus on student satisfaction has been criticised as reinforcing the notion of the student as a "consumer" (e.g. Bates \& Kaye, 2014; Jones, 2010), it is clear that satisfaction plays a key role in the successful transition and retention of students (e.g. Thomas, 2012). As such, it important to examine a number of factors relating to student satisfaction and how these may vary at different time points in the academic year. Given that we found in-group affect to be related to satisfaction at Time 2, this may call for a 
focus on building social identity processes into the day-to-day experiences of students, as a strategic approach to promote satisfaction. Nevertheless, we also recognise that student satisfaction is influenced by a multitude of factors, in addition to academic self-efficacy and social identity, which were the focus of the current study. Contextual factors such as accommodation/housing issues, financial concerns, external work pressures, and experiences of stress from heavy assessment demands, are some examples of likely contributors to perceptions of student satisfaction (Gruber, Fuss, Voss \& Gläser-Zikuda, 2010; WiersJenssen, Stensaker \& Grøgaard, 2002). It is therefore recommended that HEIs and policydriven measures of satisfaction are monitored and implemented accordingly, with greater consistency in the time and contextual parameters being determined, to avoid these confounding the data obtained.

\section{Conclusion}

The aim of the current research was to explore the extent to which pre-entry programmes foster academic self-efficacy and social identity. It also examined whether these key psychological factors are associated with successful transition experiences throughout students' first year of academic study. Findings suggest that engaging with a pre-entry programme may positively influence students' academic self-efficacy and satisfaction. It is likely that pre-entry programmes, which here have been found to be effective in fostering academic self-efficacy in particular, may ease students' transition into university and could have a long-term impact on their retention in the challenging first few weeks of term. However, social identity did not differ between those who participated in a pre-entry programme relative to typical entry route students. It is therefore suggested that pre-entry programmes should aim to fulfill a number of criteria, such as developing academic preparedness and confidence, building social capital and fostering students' sense of 
belonging, all of which may be predictive of student satisfaction across students' educational trajectory. In line with this suggestion, the current findings also revealed that academic selfefficacy was pivotal to students' positive university experience at the start of the year, whilst their sense of belonging to their institution was related to satisfaction at the end of the year. This highlights the complexities of the concept of "student satisfaction", and demonstrates the utility of examining multiple factors relating to satisfaction across different time points. This finding may be of particular importance to current HE policies and practices which typically utilise measures of student satisfaction at the end of the academic year (e.g., the National Student Survey), suggesting that such measures may be capturing a time-specific concept of satisfaction. This complexity of student satisfaction is supported by research which has suggested that composite satisfaction scores may be more useful than single-item global satisfaction scores (Elliot \& Shin, 2002) and that social climate, physical environment and other important factors should not be overlooked in attempting to consider and improve student experiences (Gruber et al., 2010; Wiers-Jenssen et al., 2002). The implications here are that a onetime measurement of student satisfaction at the end of the final year is not likely to fully capture student satisfaction with their university experience, yet this is the main metric of satisfaction that is used to compare HEIs at a national level. HEIs could therefore consider gathering data at multiple time points throughout the duration of students' academic study to capture a more accurate picture of their experiences of higher education. 


\section{References}

Bandura, A. (1986). Social foundations of thought and action: A social cognitive theory.

Englewood Cliffs, NJ: Prentice Hall.

Bandura, A. (1997). Self-efficacy: The exercise of control. New York: Freeman.

Bates, E. A., \& Kaye, L. K. (2014). 'I'd be expecting caviar in lectures': The impact of the new fee regime on undergraduate students' expectations of Higher Education. Higher Education, 67(5), 655-673. doi: 10.1007/s10734-013-9671-3

Berger, J. B., \& Malaney, G. D. (2003). Assessing the transition of transfer students from community colleges to a university. Journal of Student Affairs Research and Practice, 40(4), 533-555. doi: 10.2202/1949-6605.1277

Briggs, A. R. J., Clark, J., \& Hall, I. (2012). Building bridges: Understanding student transition to university. Quality in Higher Education, 1-19. doi: $10.1080 / 13538322.2011 .614468$

Brooman, S., \& Darwent, S. (2014). Measuring the beginning: A quantitative study of the transition to higher education. Studies in Higher Education, 39(9), 1523-1541. doi: $10.1080 / 03075079.2013 .801428$

Brimble, M. J. (2015). Does entry route really affect academic outcome? Academic achievement of traditional versus non-traditional entrants to $\mathrm{BN}(\mathrm{Hons})$ preregistration nursing programmes. Journal of Further and Higher Education, 39(3), 379-398. doi: 10.1080/0309877X.2013.858675

Cameron, J. (2004). A three-factor model of social identity. Self and Identity, 3(3), 239-262. doi: 10.1080/13576500444000047 
Chemer, M. M., Hu, L., \& Garcia, B. F. (2001). Academic self-efficacy and first year college student performance and adjustment. Journal of Educational Psychology, 93(1), 5564. doi: $10.1037 / 0022-0663.93 .1 .55$

Christie, H., Tett, L., Cree, V. E., \& McCune, V. (2014). "It all just clicked”: A longitudinal perspective on transitions within university. Studies in Higher Education. Doi: $\underline{10.1080 / 03075079.2014 .942271}$

Clemes, M. D., Gan, C. E. C., \& Kao, T. (2008). University student satisfaction: An empirical analysis. Journal of Marketing for Higher Education, 17(2), 292-325. doi: $10.1080 / 08841240801912831$

Crafter, S., \& Maunder, R. (2012). Understanding transitions using sociocultural framework. Educational and Child Psychology, 29(1), 10-18.

DeWitz, S. J., Woolsey, M. L., \& Walsh, W. B. (2009). College student retention: An exploration of the relationship between self-efficacy beliefs and purpose in life among college students. Journal of College Student Development, 50(1), 19-34. doi: 10.1353/csd.0.0049

Dodgson, R., \& Bolam, H. (2002). Student retention, support and widening participation in the north east of England. Universities for the North East. <http:// www.unis4ne.ac.uk/unew/ProjectsAdditionalFiles/wp/Retention_report.pdf>

Douglas, J., Douglas, A., \& Barnes, B. (2006). Measuring student satisfaction at a UK university. Quality Assurance in Education, 14(3), 251-267. doi: $10.1108 / 09684880610678568$ 
Ellemers, N., Gilder, D. D., \& Haslam, S. A. (2004). Motivating individuals and groups at work: A social identity perspective on leadership and group performance. Academy of Management Review, 29(3), 459-478.

Elliott, K. M., \& Healy, M. A. (2001). Key factors influencing student satisfaction relating to recruitment and retention. Journal of Marketing for Higher Education 10(4), 1-11. doi: 10.1300/J050v10n04_01

Elliott, K. M. \& Shin, D. (2002) Student satisfaction: An alternative approach to assessing this important concept. Journal of Higher Education Policy and Management, 24 (2) 197-209. doi: 10.1080/1360080022000013518

Fazey, D., \& Fazey, J. (2001). The potential for autonomy in learning: perceptions of competence, motivation and locus of control in first-year undergraduate students. Studies in Higher Education, 26(3), 345-61. doi: 10.1080/03075070120076309

Fergy, S., Heatley, S., Morgan, G., \& Hodgson, D. (2008). The impact of pre-entry study skills training programmes on students' first year experience in health and social care programmes. Nurse Education in Practice, 8, 20-30. doi: 10.1016/j.nepr.2007.02.003

Field, A. (2013). Discovering statistics using IBM SPSS statistics. London: SAGE.

Forrester, G., Motteram, G., Parkinson, G., \& Slaouti, D. (2004, Sept) Going the distance: students' experiences of induction to distance learning in higher education. Paper presented at the British Educational Research Association Annual Conference, University of Manchester, 16-18 September.

Gale, T., \& Parker, S. (2014). Navigating change: A typology of student transition in higher education. Studies in Higher Education, 39(5), 734-753. doi:

$10.1080 / 03075079.2012 .721351$ 
Gruber, T., Fuss, S., Voss, R., \& Gläser-Zikuda, M. (2010). Examining student satisfaction with higher education services: Using a new measurement tool. International Journal of Public Sector Management, 23(2), 105-123.

Harvey, L., \& Drew, S. (2006). The First Year Experience: Briefing on Induction. [Online]. Available at:

http://www.heacademy.ac.uk/assets/York/documents/ourwork/research/literature_revi ews/first_year_experience_briefing_on_induction.pdf

Howard, C., \& Davies, P. (2013). Attracting mature students into higher education: The impact of approaches to learning and social identity. Journal of Further and Higher Education, 37 (6), 769-785

Huon, G., \& Sankey, M. (2002, July), The transition to university: understanding differences in success. Paper presented at the 6th Pacific Rim First Year in Higher Education Conference: Changing Agendas, University of Canterbury, Christ- church, New Zealand, 8-10 July.

Hutchinson, L., Mitchell, C., \& St John, W. (2011). The transition experience of Enrolled Nurses at a Bachelor of Nursing at an Australian university. Contemporary Nurse, 38 (1-2), 191-200. doi: 1 0.5172/conu.2011.38.1-2.191.

Hogg, M. A., \& Abrams, D. (1988). Social identifications: A social psychology of intergroup relations and group processes. London: Routledge.

Iyer, A., Jetten, J., Tsivrikos, D., Postmes, T., \& Haslam, S. A. (2009). The more (and the more compatible) the merrier: Multiple group membership and identity compatibility as predictors of adjustment after list transitions. British Journal of Social Psychology, 48, 707-733. doi: 10.1348/014466608X397628 
James, R., Krause, K., \& Jennings, C. (2010). The First Year Experience in Australian Universities: Findings from 1994 to 2009. Centre for the Study of Higher Education: University of Melbourne.

Jones, G. (2010) Managing student expectations: The impact of top-up tuition fees. Perspectives, 14 (2) 44-48

Jungert, T. (2013). Social identities among engineering students and through their transition to work: A longitudinal study. Studies in Higher Education, 38(1), 39-52. doi: $10.1080 / 03075079.2011 .560934$

Kaye, L. K., \& Bates, E. A. (2016). The impact of higher fees on students' reasons for attending university. Journal of Further and Higher Education. doi: 10.1080/0309877X.2015.1117597

Krause, K-L., Hartley, R., James, R., \& McInnis, C. (2005). The first year experience in Australian universities: Findings from a decade of national studies. http://www.griffith.edu.au/_data/assets/pdf_file/0006/37491/FYEReport05.pdf

Leese, M. (2010). Bridging the gap: Supporting student transitions into higher education. Journal of Further and Higher Education, 34 (2), 239-251

Lent, R. W., Singley, D., Sheu, H., Schmidt, J. A., \& Schmidt, L. C. (2007). Relation of social-cognitive factors to academic satisfaction in engineering students. Journal of Career Assessment, 15(1), 87-97. doi: 10.1177/1069072706294518

Longden, B. (2006) An institutional response to changing student expectations and their impact on retention rates. Journal of Higher Education Policy and Management, 28(2) 173-187. doi: 10.1080/13600800600751044

Lowe, H., \& Cook, A. (2003). Mind the Gap: are students prepared for higher education?'. Journal of Further and Higher Education, 27(1): 53-76. doi: $10.1080 / 03098770305629$ 
Maunder, R. E., Gingham, J., \& Rogers, J. (2010). Transition in Higher Education: Exploring the experiences of first and second year psychology undergraduate students. The Psychology of Education Review, 34(1), 50-54.

McInnis, C., James, R., \& Hartley, R. (2000). Trends in the First Year Experience in Australian Universities. Canberra: Department of Education, Training and Youth Affairs.

McLoughlin, C., Brady, J., Lee, M. J. W., \& Russell, R. (2007, November). Peer-to-peer: An e-mentoring approach to developing community, mutual engagement and professional identity for pre-service teachers. Paper presented at the Australian Association for Research in Education (AARE) Conference. Fremantle, Western Australia, $25^{\text {th }}-29^{\text {th }}$ November

Murtagh, L. (2012). Enhancing preparation for higher education. Practitioner Research in Higher Education, 6 (1), 31-39.

Myers, J. L., Well, A. D., \& Lorch, R. F. (2010). Research design and statistical analysis. New York: Routledge.

Nevill, A., \& Rhodes, C. (2004). Academic and social integration in higher education: A survey of satisfaction and dissatisfaction within a first-year education studies cohort at a new university. Journal of Further and Higher Education, 28 (2), 179-193.

O’Donnell, V. L., \& Tobbell, J. (2007). The transition of adult students to Higher Education: Legitimate peripheral participation in a community of practice? Adult Education Quarterly, 57(4), 312-328. doi: 10.1177/0741713607302686

O'Shea, S. (2014). Transitions and turning points: Exploring how first-in-family female students story their transition to university and student identity formation. International Journal of Qualitative Studies in Education, 27(2), 135-158. doi: $10.1080 / 09518398.2013 .771226$ 
Obst, P. L., \& White, K. M. (2005). Three-dimensional strength of identification across group memberships: A confirmatory factor analysis. Self and Identity, 4, 9-80. doi: $10.1080 / 13576500444000182$

Pajares, F. (1996). Self-efficacy beliefs in academic settings. Review of Educational Research, 66 (4), 543-578. doi: 10.3102/00346543066004543

Quinn, J., Thomas, L., Slack, K., Casey, L., Thexton, W., \& Noble, J. (2005). From Life Crisis to Lifelong Learning: Rethinking Working-class 'Drop-out' from Higher Education. York: Joseph Rowntree Foundation.

Ramos-Sanchez, L., \& Nichols, L. (2007). Self-efficacy of first-generation and non-firstgeneration college students: The relationship with academic performance and college adjustment. Journal of College Counseling, 10(1), 6-18. doi: 10.1002/j.21611882.2007.tb00002.x

Ramsden, P. (2008). The future of Higher Education teaching and the student experience. The Higher Education Academy. Retrieved February 4, 2013. Available from: http://www.heacademy.ac.uk/resources/detail/consultations/paulramsden_teaching_an d_student_experience

Reay, D., Crozier, G., \& Clayton, J. (2010). Fitting in or standing out: Working class students in UK higher education. British Educational Research Journal, 36(1), 107-124. doi: $10.1080 / 01411920902878925$

Richardson, D. (2003). The transition to degree level study. York: Higher Education Academy. Available from: http://www.heacademy.ac.uk/assets/York/documents/resources/resourcedat abase/id506_transition_to_degree_level_study.pdf [27 June 2012].

Sanders, J., \& Higham, L. (2012). The role of higher education students in widening access, 
retention and success. A literature synthesis of the Widening Access, Student Retention and Success National Programmes Archive. [online]. York: Higher Education Academy. Retrieved March 19, 2015, from http://www.heacademy.ac.uk//resources/detail/WP_syntheses/Sanders_Higham

Scanlon, L., Rowling, L. \& Weber, Z. (2005) "You don't have like an identity ... you are just lost in a crowd": Forming a student identity in the first-year transition to university. Journal of Youth Studies, 10(2), 223-41. doi: 10.1080/13676260600983684

Schmitt, N. (2008). The interaction of neuroticism and gender and its impact on self-efficacy and performance. Human Performance, 21, 49-61. doi: 10.1080/08959280701522197

Schunk, D. H. (1995). Self-efficacy and education and instruction. In J. E. Maddux (Ed.), Self-efficacy, adaptation, and adjustment: Theory, research, and application (pp. 281303). New York: Plenum Press.

Schunk, D. H., \& Ertmer, P. A. (1999). Self-regulatory processes during computer skills acquisition: Goal and self-evaluative influences. Journal of Educational Psychology, 91(2), 251-260.

Smith, K. (2002). 'School to university: Sunlit steps, or stumbling in the dark?' Arts and Humanities in Higher Education, 2(1), 90-98. doi: 10.1177/1474022203002002007

Smith, K., \& Hopkins, C. (2005). Great expectations: Sixth-formers' perceptions of teaching and learning in degree-level English. Arts and Humanities in Higher Education, 4(3), 304-318. doi: 10.1177/1474022205056173

Tajfel, H. (1978). Differentiation between social groups. London: Academic Press. Tajfel, H. (1979). Individuals and groups in social psychology. British Journal of Social and Clinical Psychology, 18, 183-190. doi: 10.1111/j.2044-8260.1979.tb00324.x 
Tajfel, H., \& Turner, J. (1979). An integrative theory of inter-group conflict. In J. A.

Williams \& S. Worchel (Eds.), The social psychology of inter-group relations (pp. 3347). Belmont, CA: Wadsworth.

Thomas, L. (2012). Building student engagement and belonging in higher education at a time of change: Final report from the What Works? Student Retention and Success programme. York: Higher Education Academy. Retrieved March 19, 2015, from https://www.heacademy.ac.uk/sites/default/files/What_works_final_report_0.pdf

Tranter, D. (2003, July). "Fish out of Water": students from disadvantaged schools and the university experience. Paper presented at Creating Spaces: interdisciplinary writings in the Social Sciences Conference, Australian National University, Canberra, 17-18 July.

Turner, C. S. V. \& Thompson, J. R. (1993). Socializing women doctoral students: Minority and majority experiences. The Review of Higher Education, 16, 355-370.

Warin, J., \& Dempster, S. (2007). The salience of gender during transition to higher education: Male students' accounts of performed and authentic identities. British Educational Research Journal, 33(6), 887-903. doi: 10.1080/01411920701657017

Wiers-Jenseen, J., Stensaker, B., \& Grøgaard, J. B. (2002). Student satisfaction: Towards an empirical deconstruction of the concept. Quality in Higher Education, 8(2), 183-195. doi: $10.1080 / 1353832022000004377$

Wilkins, S., Butt, M. M., Kratochvil, D., \& Balakrishnan, M. S. (2015). The effects of social identification and organizational identification on student commitment, achievement and satisfaction in higher education. Studies in Higher Education. doi: $10.1080 / 03075079.2015 .1034258$

Yorke, M. (2000). Smoothing the transition into higher education: What can be learned from student non-completion. Journal of Institutional Research, 9, 35-47. 
Yorke, M., \& Longden, B. (2008). The first-year experience of higher education in the UK: Final report. York: The Higher Education Academy.

Yorke, M., \& Thomas, L. (2003). Improving the retention of students from lower socioeconomic groups. Journal of Higher Education Policy and Management, 25, 63-74. doi: $10.1080 / 13600800305737$

Zimmerman, D. W. (1987). Comparative power of student $t$ test and mann-whitney $u$ test for unequal sample sizes and variances. The Journal of Experimental Education, 55, 171174. Doi: $10.1080 / 00220973.1987 .10806451$ 